\title{
O STOSUNKU PRACY RAZ JESZCZE. HORYZONTALNE ODDZIAŁYWANIE PRAW KONSTYTUCYJNYCH A STOSUNEK PRACY
}

\author{
Abstract \\ Employment relationship revisited: horizontal impact of constitutional rights \\ vs. employment relationship
}

Adopting a perspective of the legal system's division into private law and public law, the author states that employment relationship is a legal relationship with a separate status within the domain of private legal relationships. She also demonstrates that it has an absolutely complex character along with a social goal and purpose, the latter being so far actually "undiscovered" in the legal literature. But first and foremost she claims that employment relationship, being a type of a private legal relationship, very strongly "permeates" the sphere of public law, which results from the horizontal impact of constitutional rights within employment relationship (however, it cannot be conclusively confined to any category of administrative law, despite sharing a number of similarities with a public economic enterprise or a public institution). She emphasizes that the employee is in fact employed by the workplace and not the employer, because the employer is merely a certain "body" of this workplace.

Słowa kluczowe: stosunek pracy, horyzontalne oddziaływanie praw konstytucyjnych a stosunek pracy Keywords: employment relationship, horizontal impact of constitutional rights vs. employment relationship ASJC: 3308, JEL: K31

Przedmiotowy artykuł miałby zakończyć cykl moich wcześniejszych opracowań poświęconych zagadnieniu prawnego wymiaru stosunku pracy (Musiała 2019a i 2019b). Piszę, iż „miałby zakończyć”, ponieważ - w istocie rzeczy - naukowa dyskusja w kwestii stosunku pracy winna się chyba dopiero rozpocząć. Wątków, które należałoby bowiem rozważyć w kontekście zagadnienia stosunku pracy, pozostaje bardzo wiele. W każdym razie już wiem, że przyjąwszy perspektywę podziału systemu prawa na prawo prywatne i prawo publiczne, należy powiedzieć, iż stosunek pracy stanowi odrębny w zbiorze stosunków prawa prywatnego stosunek prawny. Mam również pewność w zakresie jego absolutnie bardzo złożonej natury i - dotąd w zasadzie „nieodkrytego” w literaturze przedmiotu - jego 
celu i przeznaczenia społecznego. Ale przede wszystkim uzmysłowiłam sobie, że stosunek pracy jako rodzaj stosunku prywatnoprawnego niezmiernie silnie „przedostaje się” w przestrzeń prawa publicznego, co jest wynikiem możliwości horyzontalnego oddziaływania praw konstytucyjnych w stosunku pracy (choć nie sposób go definitywnie „zamknąć" w żadnej z kategorii prawa administracyjnego, mimo wielu podobieństw w naturze, które łączą go z publicznym podmiotem gospodarczym czy zakładem administracyjnym). Nabieram też coraz większej pewności w zakresie twierdzenia, że w istocie to zakład pracy, a nie pracodawca zatrudnia pracownika, pracodawca jest bowiem jedynie pewnym „organem” tego zakładu. Notabene mam świadomość potraktowania tej ostatniej tezy przez naukowe środowisko prawa pracy jako „rewolucyjnej”; ale też wiem, że owa reakcja wynika wyłącznie z silnego kulturowego przywiązania do postrzegania społecznych stosunków pracy w przestrzeni folwarcznej, pracodawca zaś jako podmiot zatrudniający „pasuje” wówczas idealnie - to bowiem swoisty „pan i władca”.

Porządek mojego wywodu ustalam następująco. Wpierw wskażę na kwestię wielowymiarowości prawnych stosunków budujących ów złożony stosunek prawny, jakim jest stosunek pracy (i tu krótko powtórzę swoje wcześniejsze wnioski, ponieważ w procesie prowadzonej przeze mnie ich weryfikacji utrzymały swój sens), a dalej dowiodę tezy, że stosunek pracy jako odrębny od stosunku cywilnoprawnego stosunek prywatnoprawny, bardzo mocno osadzony w przestrzeni publicznej, stanowi znakomity przykład stosunku prawnego o charakterze horyzontalnym ${ }^{1}$.

1. Próbując kompleksowo scharakteryzować ten stosunek prawny, jakim jest stosunek pracy, powiedziałabym tak: jest złożonym stosunkiem prawnym, w ramach którego występuje wiele stosunków zobowiązaniowych, spośród których najważniejszy jest prawny stosunek zobowiązania pracownika do wykonywania pracy za wynagrodzeniem. Ale - co bardzo ważne - w stosunku pracy równolegle występuje ciąg stosunków podległości kompetencji, w którym rolę zupełnie podstawową odgrywa stosunek podporządkowania pracownika poleceniom pracodawcy w zakresie konkretyzacji pracowniczego obowiązku wykonywania pracy. Tak właśnie wygląda sfera normatywna stosunku pracy. Co więcej, w moim przekonaniu, biorąc pod uwagę teoretyczną aparaturę pojęciową, stosunek pracy jest stosunkiem typu podległości kompetencji, to właśnie ten ciąg stosunków podległości kompetencji stanowi bowiem tego stosunku absolutny fundament (Ziembiński 1980, s. 324-334).

A dlaczego tak jest? Ponieważ stosunek pracy opiera się w sferze faktów na relacji władzy. Innymi słowy, ta władza buduje przestrzeń faktyczną stosunku pracy, a więc gdy rozpatruje się go jako stosunek tetyczny; w wymiarze normatywnym zaś, czyli jeśli idzie o prawne pojmowanie stosunku pracy, owa władza oznacza prawną kompetencję. Jeszcze inaczej rzecz ujmując, pracodawca zostaje wyposażony w liczne prawne normy kompetencji i w momencie skorzystania przez niego z danej kompetencji aktualizuje się obowiązek adresata normy kompetencyjnej, w tym przypadku pracownika. Jednak - jak

${ }^{1}$ Stąd za cenne traktuję rozważania Arkadiusza Sobczyka (2017). Jego spostrzeżenia dostarczają mi kolejnych dowodów dla publicznego (społecznego) wymiaru pracy, w konsekwencji czego państwo mocno ingeruje w relacje społeczne, których przedmiotem jest praca ludzka. 
się okazuje - analizując stosunek pracy, łatwo zauważyć, że nie chodzi tu wyłącznie o normy kompetencyjne z przestrzeni „prywatnej”, ale także o normy prawodawczej kompetencji pracodawcy, co sytuuje go w roli podmiotu wychodzącego z prostego schematu pojmowania podmiotu prywatnego, który przecież prawa „nie tworzy”.

Co więcej, w czasie moich badań nad stosunkiem pracy z całą mocą do mnie dotarło, że nawet wówczas gdy pracodawca w stosunku pracy korzysta ze swej prawnej kompetencji w sferze prawa prywatnego, to obok ciążącego na nim ogólnego (gdyż obowiązującego także podmioty prawa prywatnego) konstytucyjnego zakazu dyskryminacji jest adresatem nakazu równego traktowania, ujętego w podstawowych zasadach prawa pracy². To zaś musi przenosić pracodawcę absolutnie w przestrzeń prawa publicznego. Obowiązek równego traktowania podmiotów podobnych $\mathrm{z}$ istoty spoczywa bowiem wyłącznie na państwie i nie może być bezpośrednio przenoszony na podmioty prywatne; notabene powyższe wynika stąd, że w takim wypadku wymóg równego traktowania na przykład wszystkich potencjalnych klientów danego przedsiębiorcy naruszyłby swobodę podmiotu prywatnego w zakresie ich wyboru. Zatem przez wprowadzony w prawie pracy nakaz równego traktowania w zatrudnieniu (na wielu płaszczyznach tego zatrudnienia) to prawo odrywa się istotnie od modelowego ujęcia prawa prywatnego, w którym autonomia woli stron prywatnoprawnego stosunku pracy jest absolutnie najważniejsza.

Dlaczego tak właśnie się dzieje? Z jakiegoż to powodu prawodawca w zakresie tego właśnie stosunku prawnego - stosunku pracy - postanowił tak istotnie zaingerować w niego, żeby praktycznie swobodną wolę stron w zasadzie zmarginalizować. Odpowiedź jest dość prosta, choć zarazem skomplikowana. Praca jest szczególnym dobrem wspólnym. Stanowi najważniejszą wartość w aspekcie ładu społeczno-gospodarczego, a ten przecież w istotnej mierze wypełnia ład ustrojowy państwa. Innymi słowy, państwo, mając na względzie fundamentalne znaczenie pracy w aspekcie swojego ustroju, bo to jej właściwe „ułożenie” warunkuje w nim (tym państwie) porządek - bardzo silne ingeruje w ów typ stosunku prywatnoprawnego, jakim jest stosunek pracy. Nie może być zresztą inaczej. „Oddanie” bowiem pracy w „swobodny” obrót rynkowy, który rządzi się zasadą silniejszego, prowadziłoby do wykluczenia całych mas ludzi, którzy z różnych względów społecznych na tym rynku sobie nie poradzą, w wyniku czego i tak zrodzi dla instytucji państwa problem - w postaci ich społecznego wykluczenia.

Mam świadomość istniejącego w literaturze poglądu, że w sytuacji tak niejako „głębokiej” ingerencji prawodawcy w stosunek pracy można byłoby wręcz odmówić temu stosunkowi prawnemu charakteru stosunku prywatnoprawnego ${ }^{3}$. Z tym poglądem trudno mi się jednak zgodzić. Dlaczego? Otóż „pojawienie się” pracodawcy, a w zasadzie zakładu pracy w przestrzeni obrotu społeczno-gospodarczego jest wynikiem skorzystania

${ }^{2}$ Na problem równości w prawie pracy jako elementu konstruującego prawo pracy szczególnie mocno zwracał uwagę w czasie prac Komisji Kodyfikacyjnej Prawa Pracy w latach 2016-2018 prof. Arkadiusz Sobczyk. Protokoły z dyskusji na kolejnych posiedzeniach są dostępne w drodze informacji publicznej.

${ }^{3}$ W takim kierunku zdaje się zmierzać w polskiej doktrynie prawa pracy Arkadiusz Sobczyk (2017, s. 88-90). Tak traktuję rozważania tego Autora traktuję, gdy piszę o konstrukcji state action. 
przez podmiot prywatny z konstytucyjnie zagwarantowanej mu wolności działalności gospodarczej. Zakład pracy, a więc owa wspólnota ludzi to niejako wtórny skutek „zrealizowania" przez określony podmiot prawa swobody działalności gospodarczej. Państwo, w swoim „wyobrażeniu” o ładzie społeczno-gospodarczym wychodząc od traktowania pracy jako wartości społecznej, tę konstytucyjną wolność podmiotu prywatnego w sferze gospodarczej zderza z najważniejszą dla instytucji państwa i społeczeństwa wartością dobra wspólnego i solidarności. Praca, jako zjawisko społeczne, tworzy dobro wspólne; w wyniku pracy powstaje swoiste „bogactwo”, „zysk”, w którego podziale wszyscy bierzemy „udział”. Ma też owa praca absolutnie fundamentalne znaczenie, jeśli chodzi o budowanie solidarności międzyludzkiej; przede wszystkim sam wytwór pracy jednej osoby służy między innymi innemu pracującemu, który wytwarza kolejne produkty. Istotne pozostaje to, że w budowaniu więzi solidarności społecznej praca odgrywa rolę kluczową.

Innymi słowy, jeśli państwo zamierza ułożyć relacje społeczne na zasadach solidarności (a pamiętać należy, że innej formuły organizacyjnej cywilizowanych społeczeństw na razie nie wymyślono), musi ingerować w kwestię ułożenia „pracy”. Pracy jednak „upublicznić” się nie da; to znaczy, że nie sposób pozostawić jej administrowania wyłącznie „w gestii” państwa. Praca bowiem łączy się ściśle ze sferą prawa prywatnego, gdzie wolny człowiek, korzystając ze swobody działalności gospodarczej, organizuje swoje ekonomiczne przedsięwzięcie i w momencie gdy zatrudnia kolejne osoby, przybiera już nie tylko postać przedsiębiorcy, ale jest też pracodawcą, bo buduje wspólnotę ludzi - zakład pracy. W zasadzie z punktu widzenia zakładu pracy „liczy się” się przede wszystkim ów pracodawca. On bowiem będzie teraz pracą „kierował”. Jest to jednak mimo wszystko w pewnym sensie uproszczenie, dlatego że - w moim przekonaniu - tą pracą de facto administruje zakład pracy, wspólnota ludzi, a pracodawca jest jedynie swoistym „organem” tej wspólnoty. Dlaczego? Ponieważ podejmując decyzje choćby co do planu urlopów, ów pracodawca nie czyni tego, kierując się „swoim interesem”, ale dobrem zakładu pracy, niejako jego „pomyślnością”. Inaczej rzecz ujmując, winien on kolejne decyzje podejmować przez pryzmat owej wspólnoty, której w pewnym sensie tylko „przewodzi”, mając na względzie przede wszystkim dobro wspólne.

W tym miejscu chcę również powiedzieć, że uważam, iż uprawnione jest stwierdzenie, że zakład pracy to w zasadzie podmiot administrujący w znaczeniu prawa administracyjnego. Twierdzę tak dlatego, że o pracodawcy można mówić jako o podmiocie, któremu państwo zleca pewne funkcje z zakresu administracji publicznej ${ }^{5}$. Nie wyobrażam sobie stanowiska przeciwnego w tym względzie - a piszę „w zasadzie”, bo wprost ustawodawca tego w przepisach prawa nie przesądził, a owego wyraźnego ustawodawczego wskazania

\footnotetext{
${ }^{4}$ Po raz pierwszy wyraźnie ów aspekt społecznego wymiaru pracy w polskiej literaturze prawa pracy naświetlił Arkadiusz Sobczyk (2013a i 2013b).

${ }^{5}$ Koncepcję tę, a więc pojmowanie podmiotu stosunku pracy jako podmiotu administrującego, po raz pierwszy w literaturze przedstawił Arkadiusz Sobczyk (2015b, s. 105).
} 
w tej mierze teoria prawa administracyjnego wymaga. Niemniej przyjąć inaczej, czyli zaprzeczyć pojmowaniu zakładu pracy jako podmiotu administrującego, nie można, ponieważ w przeciwnym razie „postanowienia”, „decyzje” pracodawcy z zakresu na przykład udzielenia urlopu, wydania świadectwa pracy stają się oświadczeniami woli, których zgodność z prawem można badać wyłącznie na zasadach prawa prywatnego; to zaś przekreśla społeczny wymiar pracy, a przecież za takowym ustrojodawca się opowiedział.

W swoich wywodach na temat stosunku pracy wskazywałam, że przy konstrukcji stosunku pracy znajduje zastosowanie norma prawna wynikająca z przepisu art. $353^{1}$ ustawy z dn. 23 kwietnia 1964 r. - Kodeks cywilny (Dz.U. 2019, poz. 1145 tekst jedn. ze zm., dalej: „k.c.”). Tezę tę podtrzymuję. Stosunek pracy jako stosunek prywatnoprawny do pewnego stopnia jest kształtowany w drodze umowy. Ale w przypadku stosunku pracy, w sytuacji tak dalekiej ingerencji ustawodawcy, który przez przepisy prawa de facto „prawie” w całości kształtuje ów stosunek, swoboda stron jest właściwie marginalna. To rzeczywiście może rodzić uzasadnioną tezę, aby stosunek pracy przestać pojmować jako stosunek prywatnoprawny. Nie da się jednak powyższego obronić z tego względu, że zakład pracy u swojego „początku” - jak wyżej wskazałam - jest ze sfery prawa prywatnego; mówiąc językiem prawa administracyjnego, nie stanowi on podmiotu prawa publicznego, nie sposób bowiem zakwalifikować go nawet do - najbliższej mu "genetycznie” w przestrzeni prawa administracyjnego - kategorii publicznego podmiotu gospodarczego. Państwo zakładów pracy ex lege nie powołuje. Sprzyja ich powstaniu, popiera ich rozwój, ale nie „wymusza” ich powstania, nie „zakłada” ich. Państwo szanuje wolność w zakresie „decyzji” o ich powstaniu (w istocie chodzi o decyzję w zakresie powstania ekonomicznego przedsięwzięcia, a ów zakład rodzi się już wówczas samoistnie), ale kiedy już ów zakład powstanie - owo państwo ma niejako pewien schemat funkcjonowania owej wspólnoty. I wolna wola stron jest praktycznie niewielka, ale mimo wszystko można na nią wskazywać. Państwo ma jakby „gotowe” wzorce funkcjonowania zakładu pracy. Można dyskutować, na ile słusznie w prawie powszechnie obowiązującym następuje ów rozkład praw i obowiązków na wspólnotę zakładu pracy.

2. Tak traktując stosunek pracy, a więc jako stosunek prywatnoprawny, ale jednocześnie mając świadomość złożonego charakteru prywatnoprawnej kompetencji pracodawcy (a więc w sferze faktów - władzy nad pracownikiem), stawiam tezę, że w szczególności perfekcyjnie trafiona jest w ramach stosunku pracy koncepcja horyzontalnego oddziaływania praw konstytucyjnych. Stosunek pracy jest bowiem wręcz stworzony „pod koncepcję" horyzontalnego działania praw konstytucyjnych. O horyzontalnym oddziaływaniu praw konstytucyjnych mowa wówczas, gdy podmiot prywatny może się na nie bezpośrednio powoływać w stosunkach z innym podmiotem prywatnym, który w tej konfiguracji występuje jednocześnie w charakterze podmiotu zobowiązanego; ten pierwszy podmiot może dochodzić ochrony swoich praw i wolności, w tym bronić się przed roszczeniami innego podmiotu prywatnego, opierając się wyłącznie na regulacji konstytucyjnej i wskazując, że to ona jest źródłem obowiązków ciążących na tym 
drugim podmiocie (Florczak-Wątor 2014, s. 345) . Jednakże by mówić o horyzontalnym stosowaniu praw konstytucyjnych, najpierw trzeba mieć pewność, czy stosunek pracy spełnia warunki uznania go za stosunek horyzontalny. Uważam, że jak najbardziej tak właśnie jest.

W literaturze prawa konstytucyjnego wskazuje się, że stosunek horyzontalny jest stosunkiem prawnym typu zobowiązaniowego powstałym między dwoma podmiotami prywatnymi, które względem siebie pozostają w relacji równorzędnej, a pod pojęciem podmiotu prywatnego rozumie się tu każdy podmiot niepaństwowy, a zatem osobę fizyczną, grupę tych osób, osobę prawną lub jednostkę organizacyjną nieposiadającą osobowości prawnej (Florczak-Wątor 2014, s. 34-35). Innymi słowy, jak dalej pisze się w literaturze: „[...] stroną stosunku horyzontalnego może być każdy podmiot, będący beneficjentem praw i wolności determinujących treść tego stosunku" (Florczak-Wątor 2014, s. 35). I zarazem dodaje się: „Przeciwieństwem stosunku horyzontalnego jest stosunek wertykalny, łączący jednostkę i państwo, w ramach którego występuje relacja podporządkowania" (Florczak-Wątor 2014, s. 35).

Jednocześnie w doktrynie prawa konstytucyjnego wylicza się dwie podstawowe zasady rządzące stosunkiem horyzontalnym: 1) zasadę autonomii woli stron stosunku horyzontalnego oraz 2) zasadę ich równorzędnej pozycji (Florczak-Wątor 2014, s. 36-43). Z kolei we wnioskach na temat ogólnych rozważań o stosunku horyzontalnym twierdzi się tak: „Im bardziej stosunek horyzontalny upodobnia się do stosunku wertykalnego, tym bardziej uzasadniona staje się ingerencja państwa, mająca na celu ochronę praw konstytucyjnych słabszej strony tego stosunku" (Florczak-Wątor 2014, s. 60). Uważam, że ów wniosek jest najistotniejszy dla rozważań o stosunku pracy jako stosunku horyzontalnym. Przecież stosunek pracy przez rozległość kompetencyjną pracodawcy - i to zarówno w sferze prawa prywatnego, jak też prawa publicznego - wyraźnie kieruje się ku stosunkowi wertykalnemu, ale stosunkiem horyzontalnym i tak pozostaje, ponieważ „nic” nie jest w stanie niejako „odebrać” mu jego prywatnoprawnego początku. Zakład pracy (zespół ludzi) i pracodawca, który nim kieruje, pozostają podmiotami prawa prywatnego, choć tak jak powiedziałam reguły rządzące zakładem pracy przez wprowadzenie przede wszystkim owego nakazu równego traktowania czynią z niego przestrzeń publicznoprawną. Podmiot kandydujący na pracownika, chcąc „wejśćc w ową wspólnotę, nawiązuje stosunek pracy, z zasady inicjowany przez umowę prywatnoprawną, zgodnie z zasadą swobody umów, ale trzeba mieć świadomość, że postanowienia umowne są wobec norm prawnych tworzących ten stosunek pracy drugorzędne, a co więcej - nigdy nie stają się normami „kontraktowymi”. To prawodawca, a nie umowa, kreuje najważniejszą treść stosunku pracy; strony bowiem, zgodnie z zasadą swobody umów, ów stosunek pracy „modelują”, ale nie mogą tego czynić wbrew ustawie, zasadom współżycia społecznego i naturze stosunku prawnego. Jak wiadomo, w realiach stosunku pracy

${ }^{6}$ Jest to tzw. bezpośrednie oddziaływanie praw konstytucyjnych, bo zachodzi również pośrednie horyzontalne ich oddziaływanie; ono jednak jest już w domenie ustawodawcy i sądów. 
swoboda umów jest w zasadzie marginalna, a na pewno nie jest fundamentem tego rodzaju stosunku prawnego. Stąd też tak mocno ciągle podkreślam odrębność stosunku pracy jako stosunku prywatnoprawnego.

Co do wymogu równorzędności - oczywiście, nawiązujące stosunek pracy podmioty prawa wypełniają go. Są to przecież dwa podmioty ze sfery prawa prywatnego i nie mają tu znaczenia żadne występujące między nimi inne różnice; prawo prywatne działa na zasadzie ich teoretycznej równorzędności. Jak wskazuje się bowiem w literaturze:

Owa równorzędność charakteryzuje się formalną równością pozycji, a więc mocy (kompetencji) kształtowania stosunków prawnych, a od strony negatywnej brakiem imperium pozwalającym na władcze kształtowanie stosunków z innymi podmiotami (Safjan 2009, s. 342, za: Florczak-Wątor 2014, s. 39).

I tak na etapie nawiązywania stosunku pracy rzeczywiście jest, a więc można mówić w momencie jego nawiązywania o formalnej równorzędności stron. Przecież kandydujący do pracy „zawsze” może się nie zgodzić i swoją kandydaturę wycofać.

Oczywiście, może budzić wątpliwości z punktu widzenia mojego pojmowania stosunku pracy, owo wskazanie przy definicji stosunku horyzontalnego na wymóg stosunku typu zobowiązaniowego. Ale gdy przyjmuję, że stosunek pracy jest stosunkiem prawnym typu podległości kompetencji, to nie przekreślam - na co wielokrotnie zwracałam uwagę przy swoich rozważaniach nad naturą tego stosunku prawnego - iż widzę w nim również stosunek zobowiązania, bo przecież nie da się zaprzeczyć, że pracownik przyjmuje na siebie obowiązek wykonywania pracy za wynagrodzeniem, a pracodawca zobowiązuje się do wypłaty wynagrodzenia. Wskazywanie przeze mnie na stosunek pracy jako stosunek typu podległości kompetencji ma jedynie pokazać rozległość kompetencyjną pracodawcy nad pracownikiem w trakcie trwania stosunku pracy, i dla mnie ona jest najważniejsza przy postrzeganiu społecznej sytuacji pracownika.

Niemniej z punktu widzenia przedmiotowych rozważań uważam, że powyższe nie ma znaczenia. Tak czy inaczej bowiem w stosunku pracy występuje wiele prostych stosunków zobowiązania, spośród nich zaś fundamentalne jest zobowiązanie pracownika do wykonywania pracy.

W tym miejscu chciałabym również rozwiać wątpliwości Moniki Florczak-Wątor wyrażone w jej monografii na temat traktowania stosunku pracy jako stosunku horyzontalnego (2014), choć - na co należy zwrócić uwagę - ostatecznie Autorka zalicza stosunek pracy do kategorii stosunków horyzontalnych. Pisze tak:

Intuicyjnie wyczuwamy, że stosunek między [...] pracodawcą a pracownikiem nie jest stosunkiem stricte prywatnym i zawiera w sobie element o publicznym charakterze. [...] Choć w świetle przyjętej przeze mnie definicji tego rodzaju stosunki są stosunkami horyzontalnymi, to jednak właśnie z uwagi na ów element publicznoprawny w praktyce mogą pojawić się wątpliwości co do zasadności takiej kwalifikacji (Florczak-Wątor 2014, s. 35). 
Uważam, że nie ma żadnych podstaw do odmowy w procesie kwalifikowania stosunku pracy jako stosunku horyzontalnego przyznania mu tego właśnie przymiotu. Zresztą w świetle sformułowanego przez wyżej wskazaną Autorkę wniosku - o rosnącej zasadności horyzontalnego oddziaływania praw konstytucyjnych na stosunek prawny w miarę upodabniania się do stosunku wertykalnego - powtarzam już raz wyrażoną tezę, iż stosunek pracy jest wręcz wzorcowy dla jego traktowania jako stosunku horyzontalnego. Stosunek pracy opiera się na zobowiązaniu pracownika do wykonywania pracy za wynagrodzenie. Ten właśnie obowiązek jest najistotniejszy z perspektywy niejako czysto praktycznej dla zatrudnionego i podmiotu zatrudniającego.

Człowiek podejmuje pracę celem zarobku i to właśnie modelowo determinuje jego decyzję o zatrudnieniu się. Z kolei pracodawca zatrudnia nie dlatego (w sensie modelowym), by budować wspólnotę opartą na solidarności, ale żeby realizować pewne ekonomiczne przedsięwzięcie, którego albo sam jest „autorem”, albo czyni to w czyimś imieniu. Kierowanie pracą drugiego człowieka jest niczym innym w sferze faktów - jak władzą; a w przestrzeni normatywnej to kierowanie wyraża się przez normy kompetencyjne, w które ustawodawca pracodawcę wyposażył, aby w ogóle ów proces kierowania pracą był możliwy i sensowny. Tu właśnie pojawia się pewien wertykalny układ między pracownikiem a pracodawcą. Zatem zupełnie niepotrzebnie ów element publicznoprawny dekoncentruje myślenie o stosunku pracy jako stosunku horyzontalnym u Moniki Florczak-Wątor. Nie czynię Jej jednak z powyższego, zarzutu. W zasadzie rozumiem. Bierze się to $z$ faktu płytkości dotychczasowych analiz doktryny prawa pracy z zakresu stosunku pracy. Dopiero bowiem niedawno w tej materii powstały poważniejsze opracowania naukowe. W każdym razie do owego „elementu publicznoprawnego” należy podejść po prostu w ten sposób, że wpierw przyjmuje się, iż praca ludzka ma wymiar społeczny i stanowi fundament ładu społeczno-gospodarczego. To determinuje wiele prawnych regulacji, które budują stosunek pracy. Ale powyższe nie powoduje, że praca jest przez państwo „administrowana”, „upubliczniona”. Jedynie (a może „aż”) warunki jej wykonywania są „mocno” przez przepisy prawa zdeterminowane, bo praca jest podstawą ustrojową z przestrzeni społeczno-gospodarczej.

Podsumowując powyższy fragment, można powiedzieć, że administruje pracą zakład pracy (a w jego imieniu pracodawca). Niejako „wyłączenie” w dużej mierze elementu wolnościowego w stosunkach pracy i wprowadzenie nakazu równego traktowania jest jakby tego (administrowania) konsekwencją, ale sama idea wspólnoty zakładu pracy pochodzi ze „świata wolności”. Ów zakład przez pryzmat również pewnej racjonalności ekonomicznej (oczywiście, mocno przez przede wszystkim społeczny wymiar zakładu pracy niejako „stępionej”) pracą zarządza, a dokładnie: człowiekiem pracy. Zarówno zakład pracy (kierujący nim pracodawca), jak i każdy kolejny pracownik są podmiotami prawa prywatnego. Sensowne kierowanie procesem pracy wymaga pewnego układu wertykalnego między pracownikiem a pracodawcą. To powoduje też, że pracodawca rozstrzyga o wielu prawach i wolnościach pracownika, czasami wychodząc poza stosunek między pracownikiem a zakładem pracy (wtedy notabene staje się z definicji podmiotem administrującym, ponieważ zostaje wyposażony w funkcję z zakresu 
administracji publicznej). Ale ów pracodawca rozstrzyga w imieniu zakładu pracy, choć de facto rozstrzyga wspólnota zakładu pracy, a dokładnie jej „dobro”. Mając na uwadze powyższe, widoczne jest, że zupełnie niezasadne są obawy Moniki Florczak-Wątor w zakresie niemożliwości traktowania stosunku pracy jako stosunku horyzontalnego. Wręcz należałoby powiedzieć, że stosunek pracy perfekcyjnie oddaje istotę stosunku horyzontalnego.

Poza tym odmówienie traktowania zakładu pracy jako podmiotu prawa prywatnego i tym samym zakwalifikowanie go jako czy to podmiotu administracji publicznej, czy choćby publicznego podmiotu gospodarczego musiałyby doprowadzić do przekreślenia jego podmiotowości w zakresie praw i wolności konstytucyjnych. Państwo i inne instytucje publiczne (w tym władze publiczne) nie mogą bowiem być adresatami uprawnień wynikających z konstytucyjnych praw i wolności. Status podmiotów władzy publicznej jest wyraźnie uregulowany w odrębnych rozdziałach Konstytucji (Dz.U. 1997, nr 78, poz. 483 ze zm., dalej: „Konstytucja”), poza przepisami o wolnościach i prawach człowieka i obywatela, a organy władzy publicznej z istoty rzeczy wykonują zadania wynikające z ich kompetencji, a nie korzystają z praw i wolności, poza tym sfera wolności i praw obywatelskich nie przenika się ze sferą kompetencji organów władzy publicznej. Niemniej chcę wyraźnie powiedzieć, że zgłoszona w literaturze prawa pracy koncepcja Arkadiusza Sobczyka na temat traktowania pracodawcy jako organu administracji publicznej jest w istocie bardzo ciekawa (Sobczyk 2015b, s. 102). Jak rozumiem, Autorowi chodziło o zaprezentowanie modelu tzw. state action, w którym podmioty administrujące (a więc także zakład pracy) są wyposażone w prerogatywy władzy publicznej i odpowiadają na zasadach odpowiedzialności organów władzy publicznej (w polskiej regulacji prawnej chodziłoby wówczas o odpowiedzialność na podstawie przepisów art. 417 k.c. i n.). Mimo że koncepcja ta w polskim systemie prawnym de lege lata jest niemożliwa do zastosowania - ponieważ stanowi ona zawsze, niejako $\mathrm{z}$ definicji, alternatywę dla horyzontalnego oddziaływania prawa konstytucyjnych - uważam ją za godną rozważenia w teorii prawa pracy. Nawet mając świadomość obecnej niemożliwości jej praktycznego wykorzystania, twierdzę, że w gruncie rzeczy właśnie ona chyba „najszybciej” wyrwałaby postrzeganie relacji pracy w Polsce jako folwarcznych?

W kontekście całości wywodu uważam, że ów „wielki” spór w doktrynie prawa pracy na temat "prostego" zarachowania stosunku pracy jako stosunku albo „czysto" prywatnoprawnego albo "czysto" publicznoprawnego jest w zasadzie pozbawiony sensu. Zdobywająca coraz większą „sławę” koncepcja horyzontalnego wymiaru praw konstytucyjnych dowodzi, że klarowny podział na prawo prywatne i prawo publiczne się zaciera. W stosunki prawa prywatnego coraz bardziej „ingeruje” państwo, i to właśnie nie tylko ustanawiając normy imperatywne, ale też niejako „nakazując” kształtować i oceniać relacje prywatnoprawne z perspektywy konstytucyjnej, a więc pewnego porządku

Autorka pisze tak: „Doktryna state action stosowana jest w państwach, w których wyklucza się możliwość horyzontalnego działania praw konstytucyjnych, zakładając, że podmiotem odpowiedzialnym z tytułu ich naruszenia może być tylko państwo" (Florczak-Wątor 2014, s. 413). 
publicznego. A zjawisko to jest szczególnie nasilone, gdy podmiot prywatny - jak pisze Monika Florczak-Wątor - „oddaje przedmiot własności do publicznego użytku; musi wówczas tym bardziej liczyć się z ograniczeniami swojego prawa z uwagi na potrzebę ochrony praw osób, które z jego własności korzystają" (Florczak-Wątor 2014, s. 48-49).

W przypadku stosunku pracy zakład pracy (czy administrujący nim pracodawca) „oddaje” miejsca pracy, które niejako „ma”, do publicznego użytku. Znamienne jest przecież wskazywanie w potocznym języku, że pracodawca „oferuje” pracę, ma „oferty” pracy. Ale właśnie przez to, że ta oferta nie jest towarem, który wystawia do sprzedaży na wolnym rynku (bo wiąże się z pracą ludzką, łączy się z człowiekiem, którego sprzedać nie sposób), a stanowi miejsce pracy, które „zapełni” homo iuridicus prawa pracy - ów zakład pracy (będący podmiotem prawa prywatnego, bo zrodził się z „wolności”) zmierza, jako że inaczej być nie może, w świat publicznoprawnego porządku, i czyni to dla człowieka. Państwo zatem tym bardziej się aktywizuje. Musi to czynić, bo przecież najwyższą wartością jest człowiek z przyrodzoną i niezbywalną godnością. W konsekwencji państwo wprowadza liczne normy prawne ów porządek w zakładzie pracy statuujące, ale też, mając na względzie, że chodzi o szczególny typ stosunku prawnego, wyposaża podmioty prawa pracy w kompetencje prawotwórcze (bo czymże innym, jak nie tworzeniem prawa, jest zawieranie układów zbiorowych pracy czy normatywnych porozumień zbiorowych?). Z kolei przez uznanie, iż stosunek pracy kwalifikuje się jako stosunek horyzontalny, normy prawa publicznego zawarte w Konstytucji mogą stać się podstawą dla roszczeń stron stosunku pracy w sytuacji naruszeń praw i wolności konstytucyjnych.

Jednocześnie wydaje mi się, że należałoby mówić o zatrudnianiu pracownika przez zakład pracy, gdzie pracodawca jest wyłącznie jego „organem”. Innymi słowy, owszem, pracownik stosunek pracy zawiera z pracodawcą, ale ów pracodawca kwestię całokształtu zatrudnienia tego pracownika rozważa z perspektywy zakładu pracy, wspólnoty ludzi, do których ów pracownik dołącza.

Zagadnienie horyzontalnego stosowania praw konstytucyjnych otwiera problem w zakresie tego, które z praw konstytucyjnych w odniesieniu do problematyki prawa pracy (a więc praw socjalnych) mogą posiadać horyzontalny wymiar (Sobczyk 2015a, s. 115 i n.). Jak pisze bowiem Monika Florczak-Wątor (2014, s. 33):

W stosunkach horyzontalnych będą działać prawa wolnościowe i prawa negatywne, natomiast działanie pozostałych praw konstytucyjnych, tj. praw-uprawnień, praw-kompetencji i praw-instytucji, będzie zasadniczo ograniczone do stosunków wertykalnych. Nie można jednak wykluczyć, że i wśród tych ostatnich pojawią się takie prawa, które będą wykazywać horyzontalną skuteczność.

Trzeba bowiem pamiętać, że prawa i wolności konstytucyjne działają przede wszystkim w stosunkach wertykalnych; podmiotem zobowiązanym do realizacji konstytucyjnych praw i wolności są zasadniczo organy władzy publicznej (por. wyrok TK z 23 lutego 2005 r., Ts 35/04, OTK-ZU 2005, nr 1B, poz. 26). To właśnie tu tworzy się płaszczyzna do rozważań w zakresie publicznych praw podmiotowych dla stron stosunku pracy. 
Biorąc pod uwagę, że niektóre konstytucyjne prawa i wolności mogą działać wyłącznie w stosunkach wertykalnych, podmiotem zobowiązanym do zapewnienia ich realizacji będą wyłącznie organy państwowe, a więc pracownik będzie dysponował wyłącznie prawem podmiotowym publicznym.

Kończąc moje rozważania i jednocześnie zamykając ów cykl, mam wrażenie, że w zasadzie powinnam je rozpocząć. Stosunek pracy stanowi otchłań prawnych problemów, dla rozwiązania których trzeba narzędzi z zakresu przede wszystkim prawa konstytucyjnego i administracyjnego. Stosunek pracy wykazuje niewiele punktów stycznych z prawem cywilnym. Jest odrębnym od stosunku cywilnoprawnego stosunkiem prywatnoprawnym, a ową „prywatnoprawność” wywodzę z „wolności” powstania wspólnoty zakładu pracy, bo wcale nie o dobrowolność nawiązania stosunku pracy tu chodzi - przecież może on powstać wbrew woli zakładu pracy (gdy dzieje się to w trybie orzeczenia sądowego).

\section{Bibliografia}

Florczak-Wątor M. (2014) Horyzontalny wymiar praw konstytucyjnych, Kraków.

Musiała A. (2019a) Czy pracownik pozostaje $w$ relacji z pracodawca?? O naturze prawnej pracodawcy - refleksji kilka... o pracodawcy jako podmiocie administrujacym?, „Monitor Prawa Pracy" [w druku].

Musiała A. (2019b) Stosunek pracy - zagadnienia podstawowe, cz. 1: Czy kontrowersje wokół monistycznej bądź dualistycznej koncepcji stosunku pracy są rzeczywiście aktualne? Stosunek pracy - zagadnienia podstawowe, cz. 2: Kontraktowa czy deliktowa odpowiedzialność pracodawcy?, „Praca i Zabezpieczenie Społeczne” [w druku].

Safjan M. (2009) Efekt horyzontalny praw podstawowych w prawie prywatnym: autonomia woli a zasada równego traktowania, „Kwartalnik Prawa Prywatnego”, z. 2.

Sobczyk A. (2013a) Prawo pracy w'świetle Konstytucji RP, t. 1: Teoria publicznego i prywatnego indywidualnego prawa pracy, Warszawa.

Sobczyk A. (2013b) Prawo pracy w świetle Konstytucji RP, t. 2: Wybrane problemy i instytucje prawa pracy a konstytucyjne prawa $i$ wolności człowieka, Warszawa.

Sobczyk A. (2015a) Problem horyzontalnego działania praw jednostki w orzecznictwie sądów pracy [w:] M. Florczak-Wątor (red.), Sądy i Trybunały wobec problemu horyzontalnego działania praw jednostki, Kraków.

Sobczyk A. (2015b) Wolność pracy i władza, Warszawa.

Sobczyk A. (2017) Państwo zakładów pracy, Warszawa.

Ziembiński Z. (1980) Problemy podstawowe prawoznawstwa, Warszawa.

\section{Orzecznictwo}

Wyrok TK z 23 lutego 2005 r., Ts 35/04, OTK-ZU 2005, nr 1B, poz. 26. 
